\title{
PENGARUH AUDIT OPERASIONAL DAN PENGENDALIAN INTERN TERHADAP EFISIENSI BIAYA PRODUKSI
}

(Survei pada Perusahaan Manufaktur di Tasikmalaya)

\author{
Oleh : \\ Wawan Sukmana \\ Iwan Hermansyah \\ (Dosen Jurusan Akuntansi Fakultas Ekonomi Universitas Siliwangi Tasikmalaya) \\ Nunung Nurjanah \\ (Alumni Jurusan Akuntansi Fakultas Ekonomi Universitas Siliwangi Tasikmalaya)
}

\begin{abstract}
Abstrak
Penelitian ini bertujuan untuk (1) untuk mengetahui hubungan audit operasional dan pengendalian intern (2) untuk mengetahui pengaruh Audit operasional dan pengendalian intern secara parsial maupun simultan terhadap efisiensi biaya produksi pada perusahaan manufaktur di Tasikmalaya. Metode penelitian ini menggunakan metode deskriptif analitis dengan pendekatan survey. Alat analisis yang digunakan adalah analisis korelasi untuk melihat hubungan antara audit operasional dengan pengendalian intern pada perusahaan manufaktur di Tasikmalaya dan dengan regresi linier metode Path Analysis untuk mengetahui pengaruh audit operasional dan pengendalian intern baik secara parsial maupun secara simultan terhadap efisiensi biaya produksi pada perusahaan manufaktur di Tasikmalaya. Dengan taraf signifikansi $(\alpha)$ yang digunakan sebesar 0,05 . hasil penelitian menunjukkan bahwa (1) terdapat hubungan yang kuat antara audit operasional dengan pengendalian intern pada perusahaan manufaktur di Tasikmalaya; (2) audit operasional secara parsial berpengaruh signifikan terhadap efisiensi biaya produksi pada perusahaan manufaktur di Tasikmalaya; (3) pengendalian intern secara parsial berpengaruh signifikan terhadap efisiensi biaya produksi pada perusahaan manufaktur di Tasikmalaya, dan (4) audit operasional dan pengendalian intern secara simultan berpengaruh signifikan terhadap efisiensi biaya produksi pada perusahaan manufaktur di Tasikmalaya.
\end{abstract}

Kata Kunci : Audit operasional, Pengendalian intern dan efisiensi biaya Produksi,

\section{Latar Belakang}

Lingkungan dunia usaha selalu berubah seiring dengan perkembangan zaman yang terus menerus. Perubahan ini pada akhirnya akan membawa pengaruh terhadap kondisi perekonomian Indonesia yang semakin terbuka sehingga menyebabkan semakin ketatnya persaingan antar badan usaha. Kondisi ini menyebabkan semua penghasil barang dan jasa menghadapi lingkungan yang semakin kompetitif dan menuntut efisiensi tinggi dalam penggunaan sumber daya secara ekonomis.

Tuntutan untuk lebih efisien, inovatif dan konsisten dalam melakukan kegiatan merupakan keputusan yang harus dipenuhi. Semua ini akan tercapai apabila penyimpanganpenyimpangan dapat ditekan serendah mungkin, dan jika mungkin dapat dihapuskan. Pada momentum inilah peranan internal audit diperlukan dan diharapkan mampu menjawab setiap permasalahan yang terjadi. Selain melakukan pengawasan terhadap aktivitas yang dilakukan oleh personil dalam suatu badan usaha, departemen internal audit juga diharapkan dapat memberi rekomendasi atas penyimpangan yang telah dilakukan. Departemen internal audit ini haruslah bersifat independen, artinya departemen internal audit mempunyai akses untuk masuk kesemua bidang yang ada dalam usaha tersebut. Independensi ini penting untuk membatasi pengaruh departemen lain agar auditor dapat melaksanakan pekerjaannya secara bebas dan obyektif. Bebas artinya tidak ada paksaan dan tidak ada pengaruh dari pihak lain dalam melakukan pemeriksaan. Obyektif artinya melihat suatu permasalahan dengan pikiran yang jernih dan tidak memiliki kepentingan sepihak. Tanpa departemen internal audit dalam satu badan usaha akan memungkinkan penyimpangan-penyimpangan semakin sulit terlihat. Kondisi antar personel maupun dengan pihak ekstem semakin tinggi dan akhimya terjadi penggelapan dari dalam. 
Di Tasikmalaya saat ini banyak terdapat perusahaan diantara perusahaan manufaktur. Perusahaan yang tergabung dalam industri manufaktur adalah perusahaan yang kegiatannya membeli bahan baku, mengolah bahan baku kemudian menjualnya. Oleh karena itu, perusahaan manufaktur membutuhkan mesin-mesin, peralatan, kendaraan dan lain sebagainya yang dibutuhkan untuk memperlancar dan menunjang kelancaran usaha.

Seiring dengan perkembangan perusahaan, pihak pemilik perusahaan biasanya tidak terjun langsung dalam aktivitas operasi perusahaan melainkan didelegasikan kepada pihak professional yang dalam hal ini disebut manajemen. Demikian pula halnya dengan industri manufaktur, pihak perusahaan selain pemilik perusahaan tidak terjun langsung menjalankan kegiatan perusahaan tetapi menyerahkan pengelolaannya kepada pihak yang dianggap professional. Tentunya pihak manajemen diharuskan untuk mempertanggungjawabkan hasil pengolahannya kepada pemilik perusahaan. Salah satu hal yang harus dipertanggungjawabkan hasil pengelolaannya kepada pemilik perusahaan adalah masalah biaya produksi.

Dalam perusahaan industri, biaya produksi merupakan komponen biaya terbesar yang dikeluarkan oleh perusahaan, yang mana efisiensi biaya produksi dapat dikatakan efisien apabila perusahaan dapat menghasilkan pendapatan yang lebih besar dibandingkan dengan biaya yang dikeluarkan oleh perusahaan. Pada umumnya perusahaan selalu ingin mengefisienkan biaya produksi dalam setiap produksinya agar mencapai laba yang maksimum. Dari laporan laba rugi bahwa, perusahaan dapat dikatakan efisien apabila pendapatan operasi lebih besar dari biaya operasi yang dikeluarkan perusahaan sehingga akan dapat menghasilkan laba. Sebaliknya jika pendapatan operasi lebih kecil dari biaya operasi yang dikeluarkan oleh perusahaan maka perusahaan mengalami rugi dan tidak efisien dalam mengelola biaya produksi.

Jadi, perusahaan manufaktur harus mampu beroperasi secara efisien dan efektif agar dapat bersaing dengan perusahaan lain. Kemampuan bersaing itu antara lain dapat berupa produk yang kompetitif dengan mutu yang baik, yang mana untuk merighasilkan produk yang bermutu tinggi dengan harga yang tetap bersaing, sangat dipengaruhi diantaranya oleh kemampuan perusahaan dalam mengendalikan proses produksinya. Jika perusahaan mampu mengendalikan proses produksinya secara efisien dan efektif dengan tidak mengurangi mutu produk, maka perusahaan akan dapat bertahan menghadapi persaingan yang semakin ketat.

Salah satu cara untuk menilai efisiensi biaya produksi ini adalah dengan adanya suatu pemeriksaan yang dilakukan seseorang yang independen dan memastikan bahwa pengendalian intern yang berjalan telah sesuai dengan ketetapan manajemen. Pemeriksaan ini dilakukan oleh pihak intern yang disebut dengan Satuan Pengawasan Intern (SPI). Satuan Pengawasan Intern pada pimpinan adalah suatu fungsi penilaian yang independen yang ada dalam suatu organisasi dengan tujuan untuk menguji dan mengevaluasi kegiatan-kegiatan organisasi yang dilaksanakan. Melalui kegiatan operasional, SPI akan melakukan analisis dan penilaian-penilaian serta memberikan rekomendasi dan saran-saran kepada pihak manajemen.

Bagi perusahaan manufaktur audit operasional merupakan kegiatan perusahaan yang sangat penting, yang mana dengan adanya audit operasional pihak manajemen dapat mengukur dan mengevaluasi pihak perusahaan sehingga dapat memberikan informasi yang benar dan objektif bagi manajemen sebagai dasar pengambilan keputusan. Audit operasional merupakan audit atas operasi yang dilaksanakan dari sudut pandang manajemen untuk menilai ekonomi, efisiensi, dan efektivitas dari setiap atau seluruh operasi, terbatas hanya pada keinginan manajemen. Manajemen memerlukan lebih banyak informasi yang relavan atas pelaksanaan operasi mereka dan hasil yang berkaitan dari apa yang dapat ditemukan semata-mata dalam data keuangan. Manajemen mencari lebih banyak informasi untuk mempertimbangkan mutu operasi dan melakukan perbaikan operasional, yang mana kegiatan tersebut harus berjalan dengan baik sesuai dengan apa yang telah ditetapkan sebelumnya.

Bagi perusahaan manufaktur biaya produksi merupakan biaya yang sangat besar, yang mana dengan adanya audit operasional maka dapat diketahui apakah biaya produksi untuk persediaan bahan baku yang dilakukan dapat menunjang pada efisiensi dan efektivitas perusahaan. Selain itu dengan adanya pengendalian intern maka pihak perusahaan dapat mengetahui apakah biaya produksi yang dikeluarkan telah efisien sesuai dengan kebutuhan produksi. Dengan pelaksanaan audit operasional dan pengendalian intern sangatlah penting sehingga diharapkan 
efisiensi biaya produksi perusahaan dapat tercapai yaitu kegiatan produksi dari suatu perusahaan telah sesuai dengan standar yang telah ditetapkan perusahaan tersebut.

\section{Rumusan Masalah}

Dalam penelitian ini rumusan masalah yang dapat diungkapkan adalah sebagai berikut :

1. Bagaimana hubungan audit operasional dengan pengendalian intern?

2. Bagaimana pengaruh audit opersioanal dan pengendalian intern secara parsial maupun simultan terhadap efisiensi biaya produksi?

\section{Kerangka Pemikiran}

Agar perusahaan mengetahui aktivitas perusahaan berjalan sesuai dengan tujuan maka manajemen perlu menetapkan audit operasional. Audit operasional menurut Arens \& Loebbeacke yang diterjemahkan oleh Amir Abadi Jusuf (2003:4) audit operasional merupakan penelaahan atas bagian manapun dari prosedur dan metode operasi suatu organisasi untuk menilai efisiensi dan efektivitasnya, serta bertujuan menekankan pada efektivitasnya dan efisiensi, dan berorientasi pada kinerja operasi mendatang". Maka dengan pengertian tersebut yang dijadikan indikatornya yaitu efisiensi, ekonomis, dan efektivitas.

Tujuan audit operasional yang ditujukan untuk meningkatkan efektivitas dari suatu perusahaan tidak mungkin dapat tercapai bila pengendalian intern tidak dilaksanakan. Adapun tujuan audit operasional menurut Sukrisno Agoes (204:22) yaitu untuk menilai kinerja (performance) dari manajemen dan berbagai fungsi dalam perusahaan, untuk menilai efisien dan ekonomi, serta menilai efektivitas perusahaan dalam mencapai tujuan yang telah ditetapkan oleh top management.

Dalam pedoman audit operasional atas tugas dan kegiatan unit kerja BPKP (NPKP : 2003), ruang lingkup audit operasional meliputi : audit atas pertanggungjawaban keuangan dan ketaatan kepada peraturan dan perundang-undangan yang berlaku, audit atas kehematan (keekonomisan) dan daya guna (efisiensi), serta audit hasil guna (efektivitas). Sedangkan pelaksana audit operasoinal dapat dilakukan oleh salah satu dari tiga kelompok berikut : (1) internal auditor, (2) Eksternal auditor, (3) Goverment auditor.

Dalam menunjang efisiensi dan efektivitas suatu perusahaan selain diperlukan audit operasional juga diperlukan audit intern. Menurut Hiro Tugiman (2002 : 45) mengemukakan tentang pengendalian intern secara umum untuk membedakan berbagai pengawasan dalam organisasi dengan berbagai pengawasan diluar organisasi. Pengawasan internal merupakan seluruh kegiatan yang ditujukan untuk memastikan tercapainya tujuan dan sasaran organisasi. Sedangkan menurut Ikatan Akuntan Indonesia, dalam Standar Professional Akuntan Publik (2009 ) pengendalian intern adalah suatu proses yang dijalankan oleh dewan komisaris, manajemen dan personil lain entitas yang didesain untuk memberikan keyakinan memadai tentang pencapaian tiga golongan tujuan berikut ini : (a) Keandalan Pelaporan Keuangan, (b) Efektivitas dan Efisiensi Operasi, (c) Kepatuhan terhadap Hukum dan Peraturan Yang Berlaku.

Berdasarkan pendapat di atas dapat disimpulkan bahwa pengendalian intern merupakan suatu yang ditujukan untuk memastikan tercapai tidaknya tujuan dari sasaran organisasi. Dalam pengendalian intern hal-hal yang periu diperhatikan menurut Arens (2003 : 413) adalah (1) Lingkungan pengendalian, (2) Penaksiran risiko, (3) Aktivitas pengendalian, (4) Informasi dan komurikasi, dan (5) Pemantauan.

Kekuatan pengendalian intern sangat tergantung kepada orang yang melakukannya. Sebaik apapun pengendalian intern akan gagal apabila dijalankan oleh orang yang tidak kompeten. Pengendalian intern setiap entitas memiliki keterbatasan. Menurut Mulyadi (2002 : 181) keterbatasan pengendalian intern suatu entitas adalah sebagai berikut : (a) kesalahan dalam pertimbangan, (b) gangguan, (c) pengabaian oleh manajemen, (d) biaya lawan manfaat.

Dapat disimpulkan bahwa antara audit operasional dan pengendalian intern keduanya memiliki hubungan. Menurut Amir Abadi Jusuf (2003 : 766) hubungan antara audit operasional dan pengendalian intern adalah bahwa manajemen membentuk suatu struktur pengendalian intern, untuk membantu mencapai sasaran perusahaan. Sudah tentu, dua sasaran penting semua organisasi adalah efisiensi dan efektif. Berikut tiga hal penting dalam menyusun struktur pengendalian intern 
yang baik adalah : (a) Keandalan laporan keuangan, (b) ketaatan pada hukum dan peraturan yang sudah ditetapkan, (c) efisiensi dan efektivitas operasi.

Kaitan pengendalian intern dengan audit operasional adalah pengendalian intern untuk membantu sasaran perusahaan, sudah tentu dua sasaran perusahaan penting semua organisasi adalah efisiensi dan efektif. Dalam penyusunan pengendaiian intern yang baik dapat menjadi bagian audit operasional jika tujuannya adalah operasi yang efisien dan efektif.

Dengan dijalankannya audit operasional dan pengendalian intern diharapkan efisiensi biaya produksi dapat tercapai sesuai dengan keinginan perusahaan dalam mengefisiensikan biaya produksi. Menurut Henry Simamora $(1999: 300)$ bahwa efisiensi biaya produksi merupakan perbandingan atas biaya produksi yang dianggarkan terhadap biaya produksi yang dikeluarkan selama satu periode.

Dalam suatu pendekatan audit operasional menurut Sukrisno Agoes (2004 : 175) pendekatan audit yang biasa dilakukan suatu audit operasional adalah menilai efisiensi, efektivitas dan keekonomisan dari masing-masing fungsi terdapat dalam perusahaan. Menurut Arens (2003: 391) kendala di dalan suatu organisasi dimaksudkan untuk mendorong penggunaan yang efisien atas sumber dayanya, mencakup personil, umtuk mengoptimalkan sasaran perusahaan. Bagian penting dari kendali ini adalah informasi yang akurat untuk pengambilan keputusan intern. Dari kedua pendapat di atas terlihat bahwa audit operasional berhubungan dengan pengendalian intern.

Berdasarkan pendapat-pendapat di atas dapat disimpulkan bahwa pengendalian intern kemungkinan menunjang pada tercapainya sasaran perusahaan yaitu efisiensi dan cfektivitas yang merupakan bagian dari audit operasional. Untuk mendukung penyusunan pengendalian intern yang baik maka diperlukan audit operasional yang baik. Sasaran yang dicapai dari audit operasional dan pengendalian intern adalah efisiersi dan efektivitas dimana hal ini akan mempengaruhi efisiensi biaya produksi perusahaan dan salah satu penilaiannya adalah mengenai biaya sesungguhnya dan biaya yang dianggarkan. Berdasarkan kerangka pemikiran di atas, maka hipotesis dalam penelitian ini dapat dinyatakan sebagai berikut :

- Hipotesis 1

"Terdapat hubungan antara audit operasional dengan pengendalian intern".

- $\quad$ Hipotesis 2

"Audit operasional dan pengendalian intern secara parsial maupun simultan berpengaruh terhadap efisiensi biaya produksi."

\section{Metode Penelitian}

Metode yang dipergunakan dalan penelitian ini adalah metode deskriptif analisis dengan pendekatan survey. Sedangkan yang menjadi objek penelitiannya adalah audit operasional, Pengendalian Intern dan efisiensi biaya produksi. Dalam penelitian ini mempunyai 3 variabel yakni : audit operasional $\left(\mathrm{X}_{1}\right)$, pengendalian intern $\left(\mathrm{X}_{2}\right)$ dan efisiensi biaya produksi $(\mathrm{Y})$.

Dalam penelitian ini data yang diperlukan terdiri dari data primer dan data sekunder. Data primer diperoleh dari kuesioner yang ditujukan kepada responden, dengan skala pengukurannya interval. Untuk semua variabel penelitian diperoleh dari data primer dengan menggunakan kuesioner yang diberikan kepada subjek penelitian. Data sekunder diperoleh dan bersumber dari literatur, karya ilmiah yang dipublikasikan serta informasi dari instansi yang ada kaitannya dengan penelitian ini. Teknik pengambilan sampel dilakukan dengan purvosive sampling. Dari Populasi berjumlah 17 perusahaan manufaktur hanya 13 perusahaan manufaktur yang bersedia. Pengujian hipotesis digunakan analisis jalur (Path analysis). Analisis jalur digunakan dengan pertimbangan bahwa pola hubungan antar variable dalam penelitian ini adalah korelatif atau kausalitas, hubungan antar variable adalah linear dan tingkat pengukuran semua variable adalah minimal interval.

Hasil Dan Pembahasan

Audit Operasional (X1)

Pada hakikatnya Audit Operasional merupakan penelaahan atas bagian manapun dari prosedur dan metode operasi suatu organisasi untuk menilai efisiensi dan efektivitasnya, dan bertujuan menekankan pada efektivitasnya dan efisiensi, dan berorientasi pada kinerja operasi masa mendatang. 
Untuk lebih jelasnya tanggapan responden mengenai audit operasional pada Perusahaan Manufaktur di Tasikmalaya berdasarkan hasil survei terhadap 13 perusahaan, dapat dilihat dari hasil jawaban atas kuisioner. Menurut Sugiyono (2007:89) klasifikasi setiap indikator variabe! $\mathrm{X}_{1}$ (Audit Operasional) dapat dihitung dengan langkah-langkah sebagai berikut :

Nilai tertinggi secara keseluruhan $: 13 \times 5 \times 15=975$

Nilai terendah secara keseluruhan : $13 \times 1 \times 15=195$

$$
\mathrm{NJI}=\frac{\text { Data terbesar }- \text { data terkecil }}{\text { Jumlah kriteria pertanyaan }}
$$

Jadi batas intervalnya adalah $=\frac{975-195}{5}=\frac{780}{5}=156$

Klasifikasi penilaian untuk indikator adalah sebagai berikut :

$\begin{array}{lllll}\text { Nilai } & 195 & - & 351 & \text { Sangat Tidak Baik } \\ \text { Nilai } & 352 & - & 508 & \text { Tidak Baik } \\ \text { Nilai } & 509 & - & 665 & \text { Cukup } \\ \text { Nilai } & 666 & - & 822 & \text { Baik } \\ \text { Nilai } & 823 & - & 979 & \text { Sangat Baik }\end{array}$

Hasil dari penyebaran kuisioner terhadap perusahaan manufakur di Tasikmalaya dan kemudian dibuat skor, maka diperoleh angka total skor sebesar 864 , termasuk klasifikasi sangat baik. Hal ini menunjukan bahwa eksistensi audit operasional sangat baik di Perusahaan manufaktur di Tasikmalaya.

\section{Pengendalian Intern $\left(\mathrm{X}_{2}\right)$}

Pengendalian intern dirancang untuk membantu proses yang dijalankan oleh manajemen terutama dalam pelaksanaan pengendalian terhadap aktiva perusahaan, agar dalam pelaksanaan berjalannya perusahaan sesıai dengan kebijakan dan prosedur yang telah digariskan dan ditetapkan oleh manajemen.

Untuk lebih jelasnya tanggapan responden mengenai pengendalian intern pada perusahaan manufaktur di Tasikmalaya berdasarkan hasil survei terhadap 13 perusahaan, dapat dilihat dari hasil jawaban responden melalui penyebaran kuesioner .

Menurut Sugiyono (2007:89) klasifikasi setiap indikator variabel $\mathrm{X}_{2}$ (Pengendalian Intern) dapat dihitung dengan langkah-langkah sebagai berikut :

Nilai tertinggi secara keseluruhan : $13 \times 5 \times 15=975$

Nilai terendah secara keseluruhan : $13 \times 1 \times 15=195$

$$
\mathrm{NJI}=\frac{\text { Data terbesar }- \text { data terkecil }}{\text { Jumlah kriteria pertanyaan }}
$$

Jadi batas intervalnya adalah $=\frac{975-195}{5}=\frac{780}{5}=156$

Klasifikasi penilaian untuk indikator adalah sebagai berikut :

$\begin{array}{lllll}\text { Nilai } & 195 & - & 351 & \text { Sangat Tidak Baik } \\ \text { Nilai } & 352 & - & 508 & \text { Tidak Baik } \\ \text { Nilai } & 509 & - & 665 & \text { Cukup } \\ \text { Nilai } & 666 & - & 822 & \text { Baik } \\ \text { Nilai } & 823 & - & 979 & \text { Sangat Baik }\end{array}$

Untuk mengetahui interpretasi nilai total jawaban responden mengenai Pengendalian Intern pada Perusahaan telah disebar kuisioner ke perusahaan yangmenjadi subjek penelitian, dan hasilnya setelah di scoring memperoleh angka 864 termasuk klasifikasi sangat baik. Hal ini menunjukkan bahwa eksistensi pengendalian intern di Perusahaan Manufaktur Tasikmalaya termasuk sangat baik. 


\section{Efisiensi Biaya Produksi (Y)}

Tanggapan responden mengenai efisiensi biaya pada perusahaan manufaktur di Tasikmalaya berdasarkan hasil survei terhadap 13 responden, dapat dilihat dari hasil jawaban responden melalui penyebaran kuesioner yang terdiri dari pertanyaan-pertanyaan yang berkaitan dengan efisiensi biaya yang diberikan kepada 13 responden sesuai dengan sampel penelitian yang diambil.

Menurut Sugiyono (2007:89) klasifikasi setiap indikator variabel Y (Efisiensi biaya produksi) dapat dihitung dengan langkah-langkah sebagai berikut:

Nilai tertinggi secara keseluruhan $: 13 \times 5 \times 4=260$

Nilai terendah šecara keseluruhan : $13 \times 1 \times 4=52$

$$
\text { NJI }=\frac{\text { Data terbesar }- \text { data terkecil }}{\text { Jumlah kriteria pertanyaan }}
$$

Jadi batas intervalnya adalah $=\frac{260-52}{5}=\frac{208}{5}=\approx 42$

Klasifikasi penilaian untuk indikator adalah sebagai berikut :

$\begin{array}{lcccl}\text { Nilai } & 13 & - & 55 & \text { Sangat Tidak Baik } \\ \text { Nilai } & 56 & - & 98 & \text { Tidak Baik } \\ \text { Nilai } & 99 & - & 141 & \text { Cukup } \\ \text { Nilai } & 142 & - & 184 & \text { Baik } \\ \text { Nilai } & 185 & - & 227 & \text { Sangat Baik }\end{array}$

Dengan demikian bahwa nilai yang diperoleh dari perhitungan terhadap tanggapan responden atas efisiensi biaya produksi yang dilakukan pada Perusahaan Manufaktur di Tasikmalaya adalah 224 termasuk klasifikasi sangat baik. Hal ini menunjukkan ke dalam interval berkategori sangat baik yang artinya bahwa tingkat efisiensi biaya produksi perusahaan manufaktur di Tasikmalaya sangat baik.

\section{Pembahasan}

Hubungan Audit Operasional Dengan Pengendalian Intern pada Perusahaan Manufaktur di Tasikmalaya

Untuk mengetahui hubungan audit operasional dengan pengendalian intern pada Perusahaan Manufaktur di Tasikmalaya, maka dilakukan uji hipotesis. Di mana hipotesis tersebut adalah "Terdapat hubungan antara audit operasional dengan pengendalian intern". Untuk menguji hipotesis tersebut dilakukan melalui uji statistik koefisien korelasi. Koefisien korelasi ini akan menentukan tingkat hubungan variabel audit operasional $\left(X_{1}\right)$ dengan variabel pengendalian intern $\left(\mathrm{X}_{2}\right)$ diperoleh nilai korelasi 0,982 yang menunjukkan besarnya hubungan atau korelasi antara audit operasional dan penmgendalian intern. Hal ini berarti bahwa antara X1 (Audit Operasional) dan variabel X2 (Pengendalian Intern) mempunyai hubungan yang positif yaitu sebesar 0,982 atai $98,2 \%$ dan memiliki nilai signifikan sebesar 0,000 . Karena $0,000<0.005$ berarti tolak Ho dan terima Ha yang berarti bahwa terdapat hubungan audit operasional dan pengendalian intern secara signifikan. Berdasarkan penjelasan di atas maka dapat disimpulkan bahwa dengan Audit operasional yang semakin baik maka akan menunjang pengendalian intern semakin baik pula dan begitu juga sebaliknya.

Pengaruh Secara Parsial Audit Operasional terhadap Efisiensi Biaya Produksi pada Perusahaan Manufaktur di Tasikmalaya

Berdasarkan hasil pengolahan data dengan menggunakan SPSS, besar pengaruh audit operasional terhadap efisiensi biaya produksi koefisien beta $(\beta)$ atau koefisien standar (standardized coefficients). Nilai koefisien beta $(\beta)$ untuk pengaruh audit operasional terhadap efisiensi biaya roduksi pada perusahaan manufaktur adalah sebesar 0,412 dengan nilai signifikan sebesar 0,011 lebih kecil dari 0,05 berarti Ha diterima Ho ditolak. Hasil ini dapat diartikan bahwa 
dengan dijalankannya audit operasional yang baik maka efisiensi biaya produksi dapat tercapai sesuai dengan keinginan perusahaan dalam mengefisiensikan biaya produksi. Hal ini relavan dengan tiga tujuan audit operasional yaitu efisiensi, ekonomis dan efektivitas. Serta relavan dengan konsep audit operasional yang di kemukakan oleh Arrens \& Loebbeacke yang diterjemahkan oleh Amir Abadi Jusuf (2003 : 4) bahwa Audit operasional merupakan penelaahan atas bagian manapun dari prosedur dan metode operasi suatu organisasi untuk menilai efisiensi dan efektivitasnya, dan bertujuan menekankan pada efektivitas dan efisiensi, serta berorientasi pada kinerja operasi masa mendatang.

Pengaruh Secara Parsial Pengendalian Intern terhadap Efisiensi Biaya Produksi pada Perusahaan Manufaktur di Tasikmalaya

Berdasarkan hasil pengolahan data dengan menggunakan SPSS, besar pengaruh audit operasional terhadap efisiensi biaya produksi koefisien beta $(\beta)$ atau koefisien standar (standardized coefficients). Nilai koefisien beta $(\beta)$ untuk pengaruh pengendalian intern terhadap efisiensi biaya produksi pada perusahaan manufaktur adalah sebesar 0,581 derigan nilai signifikan sebesar 0,046 lebih kecil dari 0,05 berarti Ha diterima Ho ditolak. Hasil analisis tersebut dapat diartikan bahwa pengendalian intern sangat menunjang pada tercapainya sasaran perusahaan yaitu efisiensi dan efektivitas. Hal ini relevan dengan konsep tujuan pengendalian intern yang dikemukakan oleh Arens \& Loebbecke yang diterjemahkan oleh Amir Abadi Jusuf (2003: 258) yaitu : 1) keandalan laporan keuangan, 2) mendorong efisiensi dan efektivitas operasional, dan 3) ketaatan kepada hukum yang berlaku. Pada poin ke dua jelas dikemukakan bahwa tujuan dari pengendalian intern adalah mendorong efisiensi dan efektivitas operasional. Untuk tercapainya pengendalian intern maka hal-hal yang perlu diperhatikan yaitu lingku ngan pengendalian, penaksiran risiko, aktivitas pengendalian, informasi dan komunikasi, dan pemantauan. Hal ini sasuai dengan penelitian Eka Wati Kurniasih (2007) yang menunjukkan terdapat pengaruh yang signifikan pengendalian intern terhadap efisiensi biaya produksi.

\section{Pengaruh Secara Simultan Audit Operasional dari Pengendalian Intern terhadap Efisiensi Biaya Produksi}

Berdasarkan hasil perhitungan Path Analysis menggunakan SPSS di peroleh nilai korelasi antara audit operasional dan pengendalian intern terhadap efisiensi biaya produksi pada perusahaan manufaktur di Tasikmalaya sebesar 0,982 dan nilai $\left(\mathrm{R}^{2}\right)$ sebesar 0,801 artinya bahwa audit operasional dan pengendalian intern terhadap efisiensi biaya produksi pada perusahaan manufaktur di Tasikmalaya sebesar $80,1 \%$ dan sisanya sebesar 19,9\% dipengaruhi oleh faktor lain. Hasil ini menunjukkan bahwa apabila pelaksanaan audit operasional dan pengendalian intern dilakukan dengan baik maka efisiensi biaya produksi menuju semakin baik.

Dari perhitungan SPSS, diperoleh nilai $\mathrm{F}_{\text {hitung }}$ sebesar 5,876 dengan kriteria penolakan $\mathrm{H}_{0}$, jika $F_{\text {hitung }}>F_{\text {tabel, }}$, atau dengan melihat nilai $F$ sig sebesar 0,021 dan nilai ini lebih kecil dari 5\%, maka ini menunjukkan bahwa Audit Operasional dan Pengendalian Intern berpengaruh signifikan terhadap Efisiensi Biaya Produksi.

Untuk melihat pengaruh langsung dan tidak langsung antara variabel, yang disajikan dalam Tabel berikut di bawah ini: 
Tabel 5. Pengaruh Langsung dan Tidak Langsung Antar Variabel Penelitian

\begin{tabular}{|c|c|c|c|}
\hline Variabel & Pengaruh Langsung & Pengaruh tidak Langsung & Jumlah \\
\hline $\mathrm{X}:$ & \multicolumn{2}{|l|}{$\begin{array}{l}\left(\rho_{Y X 1}\right)^{2} \\
(0,412)^{2}\end{array}$} & 0,170 \\
\hline & & $\begin{array}{l}\left(r_{X 2 X 1}\right)\left(\rho_{Y X 1}\right)\left(\rho_{Y X 2}\right) \\
(0,982)(0,412)(0,581)\end{array}$ & 0,199 \\
\hline \multicolumn{3}{|c|}{ Total pengaruh $\mathrm{X}_{1}$ terhadap $\mathrm{Y}$} & 0,369 \\
\hline $\mathrm{X}_{2}$ & \multicolumn{2}{|l|}{$\begin{array}{l}\left(\mathrm{P}_{\mathrm{YX} 2}\right)^{2} \\
(0,581)^{2}\end{array}$} & 0,243 \\
\hline \multicolumn{2}{|r|}{ 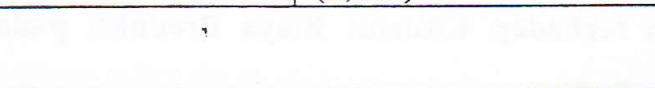 } & $\begin{array}{l}\left(r_{X 2 X 1}\right)\left(\rho_{Y X 1}\right)\left(\rho_{Y X 2}\right) \\
(0,982)(0,412)(0,581)\end{array}$ & 0,199 \\
\hline \multicolumn{3}{|c|}{ Total pengaruh $\mathrm{X}_{2}$ terhadap $\mathrm{Y}$} & 0,432 \\
\hline \multicolumn{3}{|c|}{ Total pengaruh $\mathrm{X}_{1}$ dan $\mathrm{X}_{2}$ terhadap $\mathrm{Y}$} & 0,801 \\
\hline \multicolumn{2}{|c|}{ Pengaruh Faktor Residu $\varepsilon_{2} \rightarrow \mathrm{Y}=$} & $\left(\rho_{\mathrm{YE}_{2}}\right)=1-0,801$ & 0,199 \\
\hline \multicolumn{3}{|c|}{ Total pengaruh $\mathrm{X}_{1}, \mathrm{X}_{2}$ dan $\varepsilon_{2}$ terhadap $\mathrm{Y}$} & 1,000 \\
\hline
\end{tabular}

Dari hasil analisis berdasarkan Tabel 5 menunjukkan bahwa koefisien korelasi jalur variabel $X_{1}$ (Audit Operasional) terhadap variabel $Y$ (Efisiensi Biaya Produksi) adalah sebesar 0,412 , sedangkan koefisien korelasi variabel $X_{1}$ (Audit Operasional) dengan variabel $X_{2}$ (Pengendalian Intern) adalah sebesar 0,982 dan untuk koefisien jalur variabel $\mathrm{X}_{2}$ (Pengendalian Intern) terhadap variabel Y (Efisiensi Biaya Produksi) adalah sebesar 0,581. Dengan demikian pengaruh langsung variabel $\mathrm{X}_{1}$ terhadap $\mathrm{Y}$ adalah 0,170 sedangkan pengaruh tidak langsung variabel $X_{1}$ terhadap $Y$ melalui $X_{2}$ adalah sebesar 0,369 , pengaruh langsung $X_{2}$ terhadap $Y$ adalah sebesar 0,432 . Total pengaruh $X_{1}, X_{2}$ terhadap $Y$ merupakan pengaruh secara simultan antara variabel $\mathrm{X}_{1}, \mathrm{X}_{2}$ terhadap $\mathrm{Y}$ adalah sebesar 0,801 atau sebesar $80,1 \%$. Sedangkan faktor residu atau faktor lain yang mempengaruhi laba operasi yang tidak masuk dalam variabel penelitian adalah sebesar 0,199 atau sebesar $19,9 \%$.

Faktor lain yang mempengaruhi efisiensi produksi pada Perusahaan Manufaktur di Tasikmalaya acalah penggunaan mesin-mesin yang tidak ketinggalan zaman sehingga dapat menghasilkan produk maksimal. Dengan menghasilkan produk maksimal maka akan terpenuhinya pesanan yang ditetapkan, hal ini akan mengakibatkan terjadinya kehematan terutama pada biaya produksi. Hal ini sesuai dengan yang diungkapkan oleh Rob Raider (2002: 152) yaitu "suatu kegiatan dikatakan efisien apabila dapat menghasilkan output maksimal dengan sumber daya yang ada atau dengan sumber daya yang ninimal dengan menghasilkan output tertentu".

\section{Simpulan}

berikut :

Berdasarkan hasil analisis dan pembahasan, maka dapat dibuat kesimpulan sebagai

1. Terdapat hubungan yang signifikan antara audit operasional dengan pengendalian intern pada perusahaan manufaktur di Tasikmalaya. Dengan adanya hubungan yang signifikan antara audit operasional dengan pengendalian intern maka pelaksanaan audit operasional akan mempengaruhi pengendalian intern karena bila pengendalian intern kuat maka akan memudahkan pengauditan sebab risiko audit semakin kecil.

2. Audit operasional secara parsial berpengaruh signifikan terhadap efisiensi biaya produksi pada perusahaan manufaktur di Tasikmalaya. Hasil ini dapat diartikan bahwa dengan adanya audit opersional dijalankan dengan baik maka efisiensi biaya produksi dapat tercapai sesuai dengan keinginan perusahaan dalam mengefisiensikan biaya produksi. Hal ini relavan dengan tiga tujuan audit operasional yaitu efisiensi, ekonomis, dan efektivitas.

3. Pengendalian intern secara parsial berpengaruh signifikan terhadap efisiensi biaya produksi pada perusahaan manufaktur di Tasikmalaya. Hasil ini dapat diartikan bahwa pengendalian intern sangat menunjang pada tercapainya sasaran perusahaan yaitu efisiensi dan efektivitas. $\mathrm{Hal}$ ini sesuai dengan konsep tujuan pengendalian intern menurut Amir Abadi Jusuf (2003 : 766), yaitu keandalan laporan keuangan, efisiensi dan efektivitas operasi, dan ketaatan pada hukum dan peraturan yang sudah ditetapkan. 
4. Audit operasional dan pengendalian intern secara simultan berpengaruh signifikan terhadap efisiensi biaya produksi pada perusahaan manufaktur di Tasikmalaya. Hal ini berarti semakin baik audit operasional dan pengendalian intern yang dilakukan maka akan semakin mudah tercapainya efisiensi biaya produksi. Faktor lain yang mempengaruhi efisiensi biaya produksi pada perusahaan manufaktur di Tasikmalaya adalah adanya penggunaan mesin tidak ketinggalan zaman sehingga dapat menghasilkan produk maksimal. Dengan produk maksimal akan terpenuhinya pesanan yang ditetapkan, maka akan mengakibatkan terjadinya kehematan terutama pada biaya produksi.

\section{Saran}

Berdasarkan simpulan yang telah dikemukakan di atas, penulis mencoba memberikan saransaran yang diharapkan dapat memberikan manfaat baik bagi perusanaan manufaktur maupun bagi penulis selanjutnya yang akan melaksanakan penelitian yang relevan yaitu sebagai berikut:

1). Bagi Perusahaan

Berdasarkan hasil analisis yang dilihat dari pembahasan, maka dengan adanya pengaruh audit operasional dan pengendalian intern secara parsial dan simultan terhadap efisiensi biaya produksi pada perusahaan manufaktur di Tasikmalaya, maka perusahaan harus tetap mempertahankan dan meningkatkan pelaksanaan audit operasional dan pengendalian intern yang dilakukan oleh perusahaan.

2) Bagi peneliti selanjutnya

Bagi peneliti selanjutnya yang akan melakukan penelitian yang relavan, disarankan untuk meneliti faktor-faktor lain yang mempengaruhi efisiensi biaya produksi selain audit operasional dan pengendalian intern sebagai perbandingan. Faktor lain tersebut misalnya penggunaan mesin-mesin tidak ketinggalan zaman, penetapan pesanan produk, dan kehematan biaya produksi.

\section{Daftar Pustaka}

Amin Widjava Tunggal. 2001 . Audit Operasional Pengantar. Jakarta : Harvarido

Amir Abadi Jusuf. 2003. Auditing Pendekatan Terpadu. Edisi Indonesia. Salemba Empat, Jakarta.

Arens, and Loebbecke. 2003. Auditing an Interated Approach, Alih Bahasa Amir Abadi Jusuf. Jakarta : Salemba Empat.

Suharsimi Arikunto. 2006. Prosedur Penelitian Suatu Pendekatan Praktek. Rineka Cipta. Jakarta.

Emi Auliyana. 2007. Evaluasi Efektivitas Pelaksanaan Audit Mutu Internal. http//www. Library @unair. ac.id.

BPKP. 2003. Pedoman Audit Operasional Atas Tugas dan Kegiatan Unit Kerja BPKP. Jakarta.

Eka Wati Kurniasih. 2007. Pengaruh Pengendalian Intern terhadap Efisiensi Pengendalian Biaya Produksi. http//www. Absrtakunikom. ac.id

Garisson, Ray H Noreen. 2005. Akuntansi Manajerial. Alih Bahasa Nuri Hindun Edisi 11. Buku 1. Salemba Empat : Jakarta.

Genny M. Yudawinata. 2002. Pengaruh Pelaksanaan Audit Operasional terhadap Tingkat Efektivitas pengendalian Produksi. Tasikmalaya. Unsil.

Hendry Simamora. 1999. Akuntansi Manajemen. Jakarta : Salemba Empat.

Hansen \& Mowen. Alih Bahasa oleh Thomson Learning. 2004. Manajemen Biaya Jakarta : Salemba Empat.

Hiro Tugiman. 2002. Standar Profesional Auditing Internal. Yogyakarta. Kanasius

Ikatan Akuntan Indonesia. 2002. Standar Akuntansi Keuangan. Jakarta : Penerbit-Salemba Empat.

Kusnendi. 2005. Analisis Jalur dan Aplikasi dengan program SPSS dan LISREL 8 Jurusan Pendidikan Ekonomi (JPE). PFIPS : Universitas Pendidikan Indonesia. Bandung.

Matz, Usry, dan Hammer. 1999. Akuntansi Bioya. Alih Bahasa Alfosus Sirait dan Herman Wibowo. Jakarta: PT. Gelora Aksara pratama.

Mulyadi. 2001. Akuntansi Bina. Edisi Keenam. STIE YKPN. Yogyakarta. 2002. Auditing. Buku Kesatu, Edisi Keenam. Jakarta : Salemba Empat. 
Raider Rob. 2002. Operational review : Maximal Results at Effisient Cost. John Willy \& Sons. Inc.

Sugiyono. 2006. Statistik Untuk Penelitian. Bandung : Alfabeta

Suharsimi, Arikunto. 2005. Metode Penelitian. Tarsito. Bandung.

Sukrisno Agoes. 2004. Auditing (Pemeriksaan Akuntan) oleh Kantor Akuntan Publik. Edisi Ketiga. Fakultas Ekonomi Unversitas Indonesia. Jakarta

Yuyun Supiati. 2005. Pengaruh Audit Operasional terhadap Kinerja perusahaan. Tasikmalaya. Skripsi Unsil.

Uma Sekaran. 2003. Research Method For Busines, Fourth Edition John Wiley Sons Inc. 